\title{
Maturation of the angiotensin II cardiovascular response in the embryonic White Leghorn chicken (Gallus gallus)
}

\author{
Dane A. Crossley II • Sonnet S. Jonker • \\ James W. Hicks $\cdot$ Kent L. Thornburg
}

Received: 13 October 2009 / Revised: 19 April 2010 / Accepted: 23 April 2010 / Published online: 22 May 2010

(C) The Author(s) 2010. This article is published with open access at Springerlink.com

\begin{abstract}
Angiotensin II (Ang II) is an important regulator of cardiovascular function in adult vertebrates. Although its role in regulating the adult system has been extensively investigated, the cardiovascular response to Ang II in embryonic vertebrates is relatively unknown. We investigated the potential of Ang II as a regulator of cardiovascular function in embryonic chickens, which lack central nervous system control of cardiovascular function throughout the majority of incubation. The cardiovascular response to Ang II in embryonic chickens was investigated over the final $50 \%$ of their development. Ang II produced a dose-dependent increase in arterial pressure on each day of development studied, and the response increased in intensity as development progressed. The Ang II type-1 receptor nonspecific competitive peptide antagonist $\left[\mathrm{Sar}^{1}{ }^{1} \mathrm{il}^{8}\right] \mathrm{Ang}$ II blocked the cardiovascular response to subsequent injections of Ang II on day 21 only. The embryonic pressure response to Ang II (hypertension only) differed from that of adult chickens, in which initial hypotension is followed by
\end{abstract}

Communicated by H. V. Carey.

D. A. Crossley II ( $\square)$

Department of Biology, University of North Dakota, 10 Cornell Street, Mail stop 9019, Grand Forks, ND 58202, USA

e-mail: dane.crossley@und.nodak.edu

S. S. Jonker · K. L. Thornburg

Department of Physiology and Pharmacology, Oregon Health Sciences University, Portland, OR 97201, USA

J. W. Hicks

Department of Ecology and Evolutionary Biology,

University of California, Irvine, CA 92697, USA hypertension. The constant level of gene expression for the Ang II receptor, in conjunction with an increasing pressure response to the peptide, suggests that two Ang II receptor subtypes are present during chicken development. Collectively, the data indicate that Ang II plays an important role in the cardiovascular development of chickens; however, its role in maintaining basal function requires further study.

Keywords Vertebrates - Pharmacology · Development · Physiology

\section{Introduction}

In adult mammals, rapid regulation of heart rate and arterial pressure is achieved largely by variation in sympathetic nervous outflow (Cowley et al. 1978; Iwamoto and Rudolph 1981a, b; Persson et al. 1992; Persson 1996; Liu et al. 2002; Malpas 2002). In mammals and birds, sympathetic function develops gradually over the late embryonicfetal period, and is therefore absent or limited during most of incubation or gestation (Faber et al. 1974; Assali et al. 1978; Thornburg and Morton 1986; Tazawa et al. 1992; Crossley et al. 2003a, b). In fetal mammals, several humoral mechanisms, such as catecholamines and angiotensin II (Ang II), are functional before nervous control of cardiovascular function is present. In the absence of tonic sympathetic stimulation, these alternative mechanisms maintain cardiovascular function in fetuses, as illustrated by the activation of the renin-angiotensin system (RAS) during bouts of hypoxia in fetal sheep (Lumbers et al. 2001). Embryonic chickens of the White Leghorn strain lack neural-mediated regulation of heart rate and arterial pressure throughout the majority of development (Tazawa et al. 1992; Altimiras and Crossley 2000; Crossley and 
Altimiras 2000; Crossley et al. 2003b). This relative immaturity of neural regulation may shift cardiovascular control to the RAS in embryonic chickens, as seen in fetal mammals (Crossley et al. 2003b).

Several lines of evidence suggest that the RAS is functional early in chicken development. For example, Ang II behaves as a trophic factor for cardiac and vascular development and stimulates erythropoiesis (Aceto and Baker 1990; Baker and Aceto 1990; Topouzis et al. 1992; Goutsouliak and Rabkin 1998; Le Noble et al. 2000). Further, Ang II appears to stimulate endothelial nitric oxide (NO) production in embryonic chickens, as indicated by the Ang II-induced endothelial-dependent relaxation of aortic rings (Nishimura et al. 2003). Embryonic chickens also have high levels of circulating catecholamines (Mulder et al. 2000; Crossley et al. 2003b), which could be caused by Ang II-stimulated release from adrenal tissue and sympathetic nerve terminals, as in adult vertebrates (Carroll and Opdyke 1982). In addition, embryonic chickens also possess both vascular and cardiac Ang II receptors during development (Le Noble et al. 1991; Topouzis et al. 1992; Kempf et al. 1999; Kempf and Corvol 2001; Nishimura 2001; Nishimura et al. 2003). These findings imply that the RAS is functional, although the in vivo cardiovascular response to Ang II is unknown in embryonic chickens.

The purpose of this study was to determine the cardiovascular response to Ang II in developing chickens, in order to assess its potential as a regulator of systemic blood pressure during ontogeny. To achieve this, we used an integrative approach in a series of experiments during chicken development. First, we characterized the embryonic physiological response to the hormone. Secondly, we blocked the Ang II receptor to quantify this peptide's contribution to baseline cardiovascular function. Thirdly, we quantified the amount of Ang II in the blood to determine its potential as a regulatory compound. Fourthly, we quantified the Ang II receptor gene expression that could account for any change in the cardiovascular response to the hormone over the second half of development. We tested the hypothesis that Ang II regulates basal cardiovascular function, becoming increasingly effective at raising blood pressure as development progresses.

\section{Materials and methods}

\section{Source of embryonic chickens}

Experiments were conducted in two laboratories. The initial portion of the study was conducted in the Department of Ecology and Evolutionary Biology, at the University of California, Irvine, CA, USA. For these studies, White Leghorn chicken eggs were purchased from a local hatchery
(AAA Egg Farm, Lakeview, CA, USA). The second portion of the project was conducted in the Department of Physiology and Pharmacology at Oregon Health and Science University, Portland, OR (OHSU), USA. For these studies, White Leghorn eggs were purchased from Oregon State University (Corvallis, OR, USA). At both sites, eggs were placed in incubation at $38 \pm 0.5^{\circ} \mathrm{C}$ with a relative humidity of $\approx 60 \%$, and turned automatically every $3 \mathrm{~h}$. Molecular studies were conducted in the Department of Biology at the University of North Dakota, Grand Forks, $\mathrm{ND}$, USA and at OHSU.

\section{Surgical procedures}

A saline-filled catheter was introduced into a chorioallantoic membrane (CAM) artery as previously described (Crossley and Altimiras 2000). Briefly, eggs were candled to locate the artery, and placed in a thermostatically controlled holder at $38 \pm 0.5^{\circ} \mathrm{C}$. Following removal of approximately $1 \mathrm{~cm}^{2}$ of eggshell, the artery was catheterized with heat-pulled PE-90 tubing filled with heparinized 0.9\% saline under a dissection microscope (Wild M3Z). The catheter was fixed to the shell with cyanoacrylate glue, and the egg was placed in an experimental chamber that consisted of a water-jacketed glass container. Eggs were maintained at $38 \pm 0.5^{\circ} \mathrm{C}$ and supplied with a constant flow of water-saturated air during all experiments.

\section{Signal recording and calibration}

The arterial catheter from each egg was attached to a pressure transducer (Statham 23) connected to a bridge amplifier (Gould 5900). Arterial pressure $\left(P_{\mathrm{A}}\right)$ signals were stored in a computer (Macintosh G3) using a PowerLab data acquisition system (PowerLab/8SP, Adinstruments, Colorado Springs, CO, USA) and PowerLab software (Chart 5.0). Heart rate $\left(f_{\mathrm{H}}\right)$ was continuously derived from the $P_{\mathrm{A}}$ signal. In all cases, the reference zero was set at the top of the covered glass experimental chamber. Egg distance from the top of the chamber was then measured $(\mathrm{cm})$ and used to correct for the actual position of the egg below the top of the chamber, as previously described (Altimiras and Crossley 2000).

\section{Experimental protocol}

The study consisted of four different experimental series. Each embryo was used in only one series. Series I, II, and III began with a 1-h post-surgery recovery period to allow $P_{\mathrm{A}}$ and $f_{\mathrm{H}}$ to stabilize. Data from embryonic animals that did not stabilize were not included. Pharmacologic agents were administered via a $\mathrm{T}$ connector in the arterial catheter line. Each drug injection was followed by a saline flush that 
was twice the volume of the drug mixture. Total injection volumes were $<5 \%$ of the total blood volume, based on prior quantifications (Romanoff 1960, 1967). The flush volume had no significant effect on cardiovascular function, as previously reported in embryonic chickens (Altimiras and Crossley 2000). Blood samples (Series III) were also taken from the $\mathrm{T}$ connector in the arterial line. For all experimental series, 20-day-old embryonic chickens were defined as internally pipped eggs (rupture of the air-cell), verified by candling, and 21-day-old embryonic chickens were defined as embryos that were externally pipped (rupture of the eggshell). Series I, II, and III experiments were conducted on embryos at days $13,17,19,20$, and 21 of incubation, with a total of 170 embryonic chickens studied over the course of the project.

In Series I experiments, mean arterial pressure $\left(P_{\text {mean }}\right)$ and $f_{\mathrm{H}}$ were measured during serial injections of native chicken Ang II (Bachem), given in increasing dosages at $100,250,500,1,000$, and 2,000 $\mathrm{ng} / \mathrm{kg}$ to embryonic chickens on each of the five studied days. This dosage range was selected to mirror prior work in adult chickens (Nakamura et al. 1982). In all cases, the embryonic mass, which was used to determine the drug dosage, was estimated based on published mass data (Romanoff 1960, 1967). Between each injection, $P_{\text {mean }}$ and $f_{\mathrm{H}}$ were allowed to return to preinjection values for $30 \mathrm{~min}$ before the next injection was given. In a separate group of embryonic chickens, the response to a single injection of Ang II $(1,000 \mathrm{ng} / \mathrm{kg})$ was determined on the designated days, to demonstrate the lack of tachyphylaxis during the dose-response study.

In Series II experiments, the role of systemic Ang II in maintaining basal $P_{\text {mean }}$ and $f_{\mathrm{H}}$ was assessed by blocking the Ang II receptor with the nonspecific competitive peptide antagonist $\left[\mathrm{Sar}^{1}\right.$ ile $\left.^{8}\right]$ Ang II (Sigma-Aldrich; 4,000 ng/ $\mathrm{kg}$ ). This peptide was selected based on prior studies demonstrating that it completely eliminated or dramatically attenuated the cardiovascular response to Ang II in adult chickens (Nakamura et al. 1982; Nishimura et al. 1982). The effectiveness of this antagonist was determined by comparing the response to a single injection of Ang II $(1,000 \mathrm{ng} / \mathrm{kg}) 30 \mathrm{~min}$ after the blockade to the response of a separate group treated with Ang II $(1,000 \mathrm{ng} / \mathrm{kg})$ only. [Sar ${ }^{1}$ ile $^{8}$ ] Ang II was previously shown to effectively block the Ang II type-1 receptor for 60-120 min after injection (Regoli et al. 1974; Fluharty and Reagan 1989).

In the Series III experiments, sequential blood samples (four samples of $100 \mu \mathrm{l}$ each) were collected from each instrumented embryo following a 1-h control period. All samples were mixed with $5 \mu \mathrm{L}$ of a $15 \%$ EGTA solution. The initial sample volume from all age groups represented less than $5 \%$ of the embryonic blood volume, based on published values (Romanoff 1960, 1967). This is well below the $16-21 \%$ blood volume reduction needed to induce a cardiovascular response in some adult birds (Ploucha and Fink 1986) and is similar to that taken from adult birds to quantify Ang I (Nishimura et al. 1981b). These samples were immediately centrifuged at $10,000 \mathrm{~g}$ for $10 \mathrm{~min}$ to separate the plasma. Plasma Ang II concentrations in each sample volume were determined by radioimmunoassay (Peninsula Laboratories) kit RIK 7002, as previously described (Giraud et al. 2005). At the completion of these studies, embryonic chickens were euthanized with an overdose of pentobarbital and $\mathrm{KCl}$.

In the Series IV experiments, six embryonic chickens on each day of incubation $(13,17,19$, and 20) were used for collection of cardiac and CAM tissue, following euthanasia with an overdose of pentobarbital. These tissues were used for extraction and measurement of angiotensin receptor messenger RNA levels using quantitative real-time PCR as described in Rhen et al. (2007). Flash-frozen tissues were homogenized, and total RNA was extracted using an RNeasy midi kit (Qiagen). Total RNA concentration was determined using a Nanodrop spectrophotometer (Nanodrop Technologies, Wilmington, DE, USA). An aliquot of total mRNA from each sample was run on a formaldehydeagarose gel to determine extracted RNA quality as indicated by discrete $18 \mathrm{~S}$ and $28 \mathrm{~S}$ rRNA bands. Total RNA (400 ng) was reverse-transcribed in a $20 \mu \mathrm{l}$ reaction, using an iScript cDNA Synthesis kit containing a blend of oligo dT and random hexamer primers (BioRad, Hercules, CA, USA).

The following method was used to amplify specific PCR products from the cDNA pool: primers for the chicken Ang II receptor were designed using the Primer Express v2 (ABI Prism) software, based on the existing Ang II receptor sequence for the chicken (forward $6795^{\prime}$ TGG CCA TAG TGC ATC CAG TG 3' reverse 729 5' CAA CAA ACA TGG TAC GTC GGA 3') (Kempf et al. 1996, Accession \# NM 205157). Primers for the $18 \mathrm{~S}$ rRNA were based on the existing sequence for the mouse (forward 1,275, 5' GAC ACG GAC AGG ATT GAC AGA TTG ATA G $3^{\prime}$ and reverse $1,403,5^{\prime}$ GTT AGC CCA GAG TCT CGT TCG TT 3', Accession \# NR 003278). Sequence alignment analysis revealed a single base difference in these primers between the mouse and chicken 18S rRNA (van Tuinen et al. 2000, Accession \# AF 173612). These primers were used to measure the amount of Ang II receptor mRNA and $18 \mathrm{~S}$ rRNA in each sample, using a QuantiTect SYBR Green PCR Kit and an Applied Biosystems 7300 Real Time PCR system, following standard methods described in Rhen et al. (2007). A serial dilution of the purified initial PCR product was used to produce a standard curve with a 7-log order range starting with $5 \times 10^{6}$ attograms (ag)/tube. These standard curves were used to estimate the amount of mRNA (or, more precisely, cDNA synthesized from the mRNA) per $5 \mathrm{ng}$ of total RNA extracted from the tissue. In preliminary studies, these PCR products were sequenced to 
verify that the product was homologous to the region of the chicken Ang II receptor cDNA and the mouse 18S rRNA used to design the primers.

\section{Statistical analysis}

A one-way ANOVA (repeated measures design and an LSD post hoc comparison) was used to assess the response to each Ang II dose when compared with control values, as well as the dose-dependent differences within each age group studied (Statistica V5.1). This method was also used to determine the response to serial blood sampling on plasma Ang II concentrations. A one-way ANOVA was used to assess differences in plasma Ang II levels between age groups. An unpaired $t$ test was used to assess significant differences in the $P_{\text {mean }}$ and $f_{\mathrm{H}}$ responses to $1,000 \mathrm{ng} / \mathrm{kg}$ Ang II injected during the dose-response experiments, compared to the single injection of this dose within each age group only. A paired $t$ test was used to determine statistical differences in $P_{\text {mean }}$ and $f_{\mathrm{H}}$ following the injection of the Ang II receptor-blocking agent $\left[\mathrm{Sar}^{1}\right.$ ile $\left.^{8}\right]$ Ang II within each age group. A one-way ANOVA on the arcsine transformed percentage change in $P_{\text {mean }}$ and $f_{\mathrm{H}}$ for each dosage of Ang II was used to assess statistical differences in the response between age groups. A one-way ANOVA was also used to determine statistical differences in $P_{\text {mean }}$ and $f_{\mathrm{H}}$ following an Ang II injection $(1,000 \mathrm{ng} / \mathrm{kg})$ after treatment with the blocking agent $\left[\mathrm{Sar}^{1}{ }^{1} \mathrm{ile}^{8}\right]$ Ang II, compared to a separate group of embryonic chickens treated with $1,000 \mathrm{ng} / \mathrm{kg}$ Ang II, within each age group studied.

Gene expression patterns were compared using a one-way ANOVA with sampling day as the independent variable and threshold cycle (Ct value) as the dependent variable. The $\mathrm{Ct}$ values for $18 \mathrm{~S}$ rRNA were used as a covariate to control for potential variation in the quality of input RNA as well as variation in the efficiency of the reverse transcription reaction.

All data are presented as mean \pm SE. The total number of embryos used on specific days of development for each
Table 2 Change in $P_{\text {mean }}$ and $f_{\mathrm{H}}$ following a cumulative dose of [Sar ${ }^{1}$ ile ${ }^{8}$ ] Ang II $(4,000 \mathrm{ng} / \mathrm{kg})$

\begin{tabular}{lrll}
\hline Day & $n$ & $\Delta P_{\text {mean }}(\mathrm{kPa})$ & $\Delta f_{\mathrm{H}}\left(\mathrm{min}^{-1}\right)$ \\
\hline 13 & 6 & $0.16 \pm 0.02$ & $4 \pm 4$ \\
17 & 6 & $0.37 \pm 0.07$ & $-0.2 \pm 1$ \\
19 & 6 & $0.40 \pm 0.06^{*}$ & $3 \pm 4$ \\
20 & 10 & $0.34 \pm 0.05^{*}$ & $8 \pm 3$ \\
21 & 6 & $0.26 \pm 0.09$ & $11 \pm 5$ \\
\hline
\end{tabular}

Data are presented as the mean $\pm \mathrm{SE}$

* A significant $(p<0.05)$ change from control $P_{\text {mean }}$ values

Table 3 Ang II plasma concentrations $\left(\mathrm{pg} \mathrm{ml}^{-1}\right)$ in White Leghorn chicken embryos following four sequential blood samples of $100 \mu \mathrm{l}$ each

\begin{tabular}{lrllll}
\hline Day & $n$ & 1st sample & 2nd sample & 3rd sample & 4th sample \\
\hline 13 & 7 & $170 \pm 23_{\mathrm{ab}}$ & $157 \pm 13_{\mathrm{ab}}$ & $140 \pm 11_{\mathrm{a}}$ & $176 \pm 30_{\mathrm{a}}$ \\
17 & 9 & $176 \pm 19_{\mathrm{a}}$ & $194 \pm 15_{\mathrm{a}}$ & $188 \pm 18_{\mathrm{b}}$ & $181 \pm 23_{\mathrm{a}}$ \\
19 & 12 & $115 \pm 11_{\mathrm{c}}$ & $111 \pm 10_{\mathrm{bc}}$ & $113 \pm 10_{\mathrm{a}}$ & $101 \pm 17_{\mathrm{b}}$ \\
20 & 6 & $123 \pm 17_{\mathrm{bc}}$ & $100 \pm 22_{\mathrm{c}}$ & $139 \pm 12_{\mathrm{a}}$ & $150 \pm 20_{\mathrm{ab}}$ \\
21 & 6 & $209 \pm 47_{\mathrm{a}}$ & $151 \pm 21_{\mathrm{ac}} *$ & $146 \pm 11_{\mathrm{ab}} *$ & $160 \pm 29_{\mathrm{a}}^{*}$ \\
\hline
\end{tabular}

Data are presented as a mean \pm SE. Like letters for each sample indicate similar plasma Ang II concentrations across the age groups sampled

* Significant $(p<0.05)$ concentration differences between blood samples for a given age group

experimental series is presented in Tables 1, 2, and 3. For all statistical tests, a $p$ value of $<0.05$ was considered significant.

\section{Results}

Control values for $P_{\text {mean }}$ and $f_{\mathrm{H}}$ (Table 1) were similar to those previously reported for embryonic White Leghorn chickens (Tazawa et al. 1992; Crossley and Altimiras 2000). During each dose-response study, the control values for $P_{\text {mean }}$ did not change significantly between injections at

Table 1 Baseline $P_{\text {mean }}$ and $f_{\mathrm{H}}$ for embryonic White Leghorn chickens under control conditions and the $\Delta P_{\text {mean }}(\mathrm{kPa})$ within each embryonic age in response to either increasing doses of Ang II or a single injection of $1,000 \mathrm{ng} / \mathrm{kg}(1,000 \mathrm{~s})$ in a separate group of chickens

\begin{tabular}{|c|c|c|c|c|c|c|c|c|c|}
\hline \multirow[t]{2}{*}{ Age } & \multirow[t]{2}{*}{$n$} & \multirow[t]{2}{*}{$P_{\text {mean }}$} & \multirow[t]{2}{*}{$f_{\mathrm{H}}\left(\min ^{-1}\right)$} & \multicolumn{6}{|c|}{$\Delta P_{\text {mean }}(\mathrm{kPa})$ Ang II Dose $(\mathrm{ng} / \mathrm{kg})$} \\
\hline & & & & 100 & 250 & 500 & 1,000 & 2,000 & $1,000 \mathrm{~s}$ \\
\hline 13 & $6(7)$ & $0.78 \pm 0.05$ & $239 \pm 3$ & $0.12_{\mathrm{a}}$ & $0.21_{\mathrm{ab}}$ & $0.26_{\mathrm{bc}}$ & $0.31_{\mathrm{c}}$ & $0.41_{\mathrm{d}}$ & $0.29_{\mathrm{c}}$ \\
\hline 17 & $8(8)$ & $1.94 \pm 0.05$ & $259 \pm 3$ & $0.21_{\mathrm{a}}$ & $0.30_{\mathrm{a}}$ & $0.46_{b}$ & $0.74_{c}$ & $0.89 \mathrm{c}$ & $0.85_{c}$ \\
\hline 19 & $8(10)$ & $2.31 \pm 0.08$ & $250 \pm 3$ & $0.23_{\mathrm{NS}}$ & $0.44_{a}$ & $0.61_{\mathrm{a}}$ & $0.99_{b}$ & $1.20_{\mathrm{b}}$ & $1.08_{\mathrm{b}}$ \\
\hline 20 & $7(6)$ & $2.75 \pm 0.07$ & $268 \pm 4$ & $0.62_{\mathrm{a}}$ & $0.86_{a}$ & $0.83_{\mathrm{a}}$ & $1.59_{\mathrm{b}}$ & $1.69_{\mathrm{b}}$ & $1.32_{\mathrm{b}}$ \\
\hline 21 & $6(6)$ & $2.85 \pm 0.10$ & $287 \pm 4$ & $0.43_{\mathrm{a}}$ & $0.96_{b}$ & $1.14_{\mathrm{b}}$ & $1.69_{\mathrm{c}}$ & $1.64_{c}$ & $1.56_{c}$ \\
\hline
\end{tabular}

Different letters between pressure responses to the increasing doses of Ang II indicate significant $(p<0.05)$ differences in the response intensity within an age group. All $\Delta P_{\text {mean }}$ were significant $(p<0.05)$ unless noted by NS. The data are presented as mean \pm SE. The number of embryos treated with a single injection of Ang II is indicated in parenthesis 

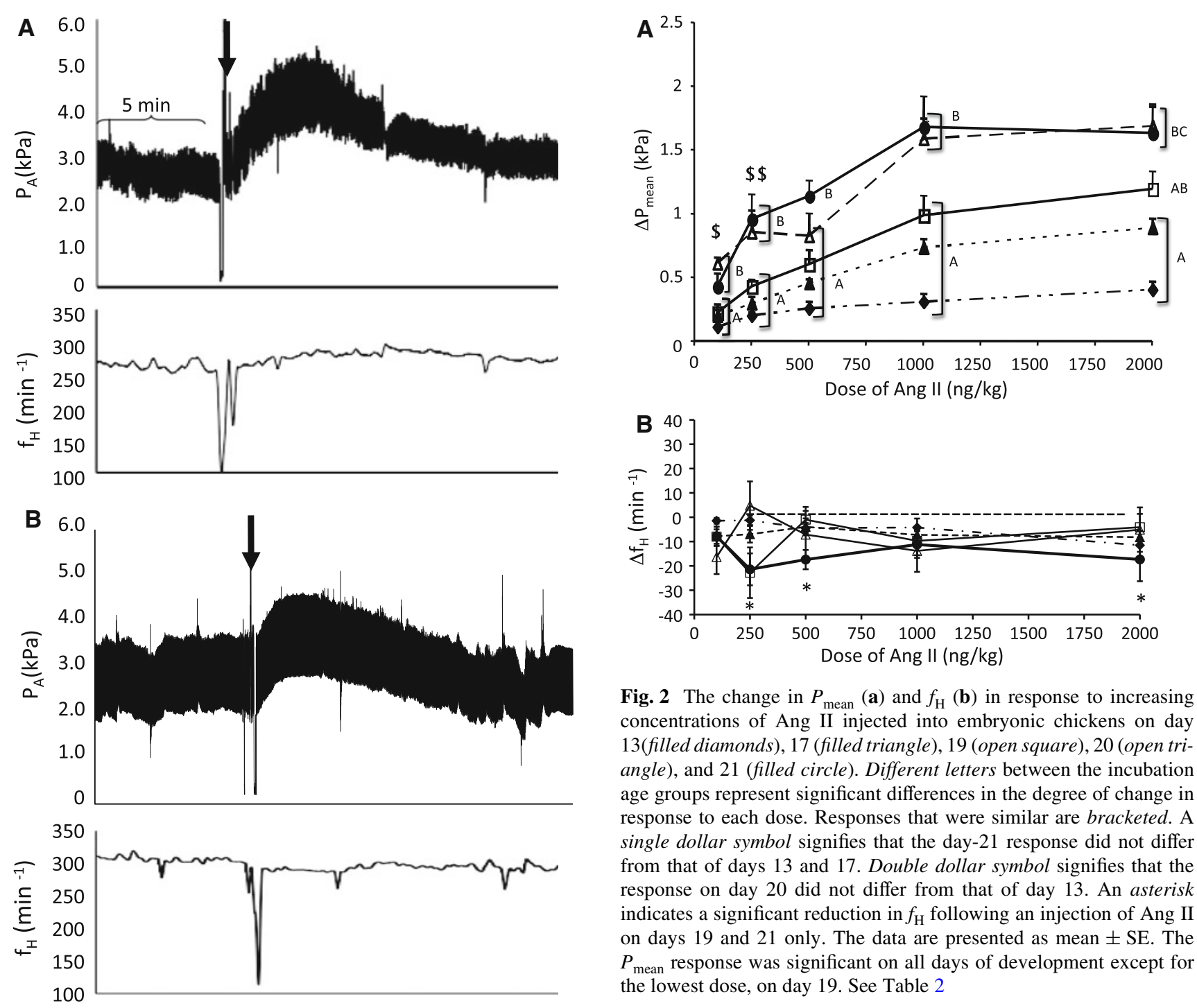

Fig. 2 The change in $P_{\text {mean }}(\mathbf{a})$ and $f_{\mathrm{H}}$ (b) in response to increasing concentrations of Ang II injected into embryonic chickens on day 13(filled diamonds), 17 (filled triangle), 19 (open square), 20 (open triangle), and 21 (filled circle). Different letters between the incubation age groups represent significant differences in the degree of change in response to each dose. Responses that were similar are bracketed. A single dollar symbol signifies that the day-21 response did not differ from that of days 13 and 17. Double dollar symbol signifies that the response on day 20 did not differ from that of day 13. An asterisk indicates a significant reduction in $f_{\mathrm{H}}$ following an injection of Ang II on days 19 and 21 only. The data are presented as mean \pm SE. The $P_{\text {mean }}$ response was significant on all days of development except for the lowest dose, on day 19. See Table 2

Fig. 1 Representative traces from two different 21-day-old embryonic chickens. These traces illustrate the arterial pressure $\left(P_{\mathrm{A}}\right)$ and heart rate $\left(f_{\mathrm{H}}\right)$ response to an injection of a Ang II $(1,000 \mathrm{ng} / \mathrm{kg})$ alone, and b after pretreatment with $\left[\mathrm{Sar}^{1}\right.$ ile $\left.^{8}\right]$ Ang II $(4,000 \mathrm{ng} / \mathrm{kg})$. For each trace, the arrow indicates the point of Ang II $(1,000 \mathrm{ng} / \mathrm{kg})$ injection. The bracket indicates a period of $5 \mathrm{~min}$

any stage of development. The general response to Ang II, regardless of dose, was a rapid rise in blood pressure followed by a return to control levels (Fig. 1a). Unlike $P_{\text {mean }}$, Ang II produced inconsistent $f_{\mathrm{H}}$ changes on days 19 and 21 only, with a bradycardic response to $250 \mathrm{ng} / \mathrm{kg}$ on both days, and a bradycardic response to 500 and 2,000 $\mathrm{ng} / \mathrm{kg}$ on day 21 only (Fig. 2b).

\section{Series I}

All doses of Ang II increased $P_{\text {mean, }}$ with the exception of the $100 \mathrm{ng} / \mathrm{kg}$ dose injected on day 19 (Table 1, Fig. 2a).

The intensity of the pressure response increased in a dose-dependent manner in all age groups, with the increase ranging from 11 to $66 \%$ (Table 1). Select doses of Ang II caused significant bradycardia on days $19(250 \mathrm{ng} / \mathrm{kg})$ and 21 (250, 500, and 2,000 ng/kg) (Fig. 2b). The 1,000 ng/kg dose of Ang II elicited the maximal $P_{\text {mean }}$ response on all days studied, except day 13 , which increased further with the $2,000 \mathrm{ng} / \mathrm{kg}$ dose (Table 1). An age comparison of the maximal change in $P_{\text {mean }}$ induced by an injection of Ang II revealed a significant $(p<0.05)$ change in the hypertensive response with age, from a $31 \%$ increase on day 13 to a $66 \%$ increase on day 21 (Fig. 2a).

In an effort to ensure the absence of tachyphylaxis to Ang II during the dose-response series, the $P_{\text {mean }}$ response to Ang II $(1,000 \mathrm{ng} / \mathrm{kg})$ given as a single injection was compared to the increase when Ang II was injected during the dose-response series. This comparison revealed no 


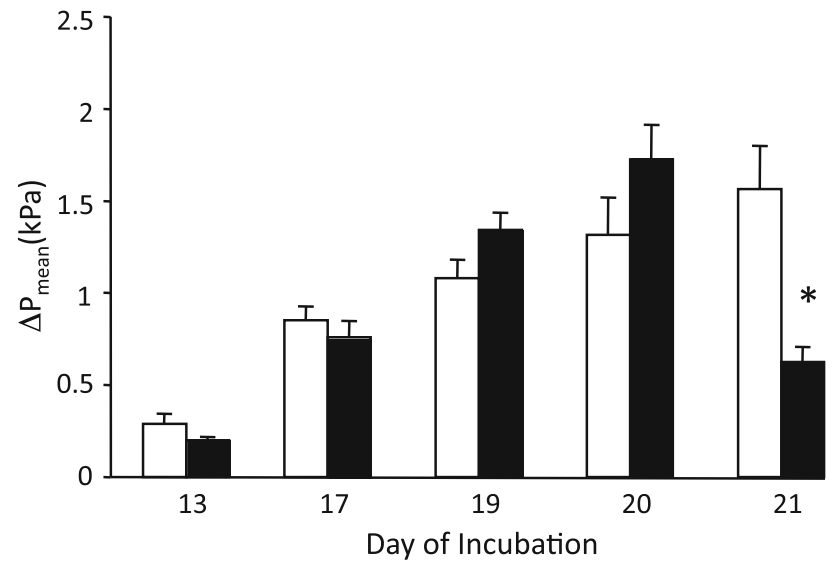

Fig. 3 The peak change in $P_{\text {mean }}$ following an injection of Ang II $1,000 \mathrm{ng} / \mathrm{kg}$ when given as a single injection (open bar), or in a separate group following pre-injection with $\left[\mathrm{Sar}^{1}\right.$ ile $\left.^{8}\right]$ Ang II $4,000 \mathrm{ng} / \mathrm{kg}$ (filled bar). An asterisk indicates a significant $(p<0.05)$ difference in the pressure response between the two injections on a given day of incubation. The data are presented as mean $\pm \mathrm{SE}$

difference between the two protocols in all age groups studied (Table 1).

\section{Series II}

Pretreatment with the Ang II type-1 receptor nonspecific competitive peptide antagonist $\left[\mathrm{Sar}^{1}\right.$ ile $\left.^{8}\right]$ Ang II $(4,000$ $\mathrm{ng} / \mathrm{kg}$ ) significantly elevated $P_{\text {mean }}$ on days 19 and 20 (Table 2). This blocking agent reduced the intensity of Ang II-induced hypertension $(1,000 \mathrm{ng} / \mathrm{kg})$ on day 21 only (Fig. 3). Pretreatment with $\left[\mathrm{Sar}^{1}\right.$ ile $\left.^{8}\right]$ Ang II $(4,000 \mathrm{ng} / \mathrm{kg})$ did not alter $f_{\mathrm{H}}$ (Table 2).

\section{Series III}

Plasma concentrations of Ang II were high throughout the developmental period studied, averaging $160 \mathrm{pg} \mathrm{ml}^{-1}$ (Fig. 4). Plasma Ang II levels significantly dropped on day 19, but returned to pre-day 19 levels by day 21 (Fig. 4). Multiple acute blood samples had no impact on plasma Ang II concentrations, with the exception of those taken on day 21, when Ang II concentration decreased (Table 3).

\section{Series IV}

The efficiencies of the quantitative PCR reaction for both the Ang II receptor cDNA and 18S rRNA averaged $~ 85 \%$ during the incubation period studied. The Ang II receptor mRNA concentrations in the CAM averaged $\sim 1,500$ ag $\times 5 \mathrm{ng} \mathrm{RNA}^{-1}$ with a trend toward decreasing at day 20 (Fig. 5a). A similar trend was evident in the embryonic heart, which averaged $490 \mathrm{ag} \times 5$ ng RNA ${ }^{-1}$ (Fig. 5b).

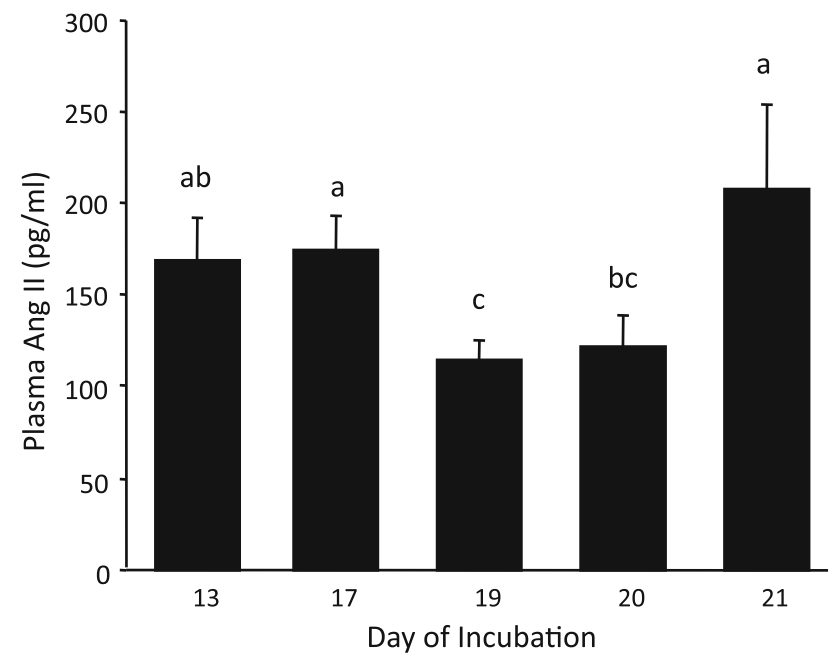

Fig. 4 The control plasma Ang II concentrations in embryonic chickens during the period of development studied. Different letters between any two incubation age groups indicates a significant $(p<0.05)$ difference in the plasma Ang II concentration between the groups. The data are presented as mean $\pm \mathrm{SE}$
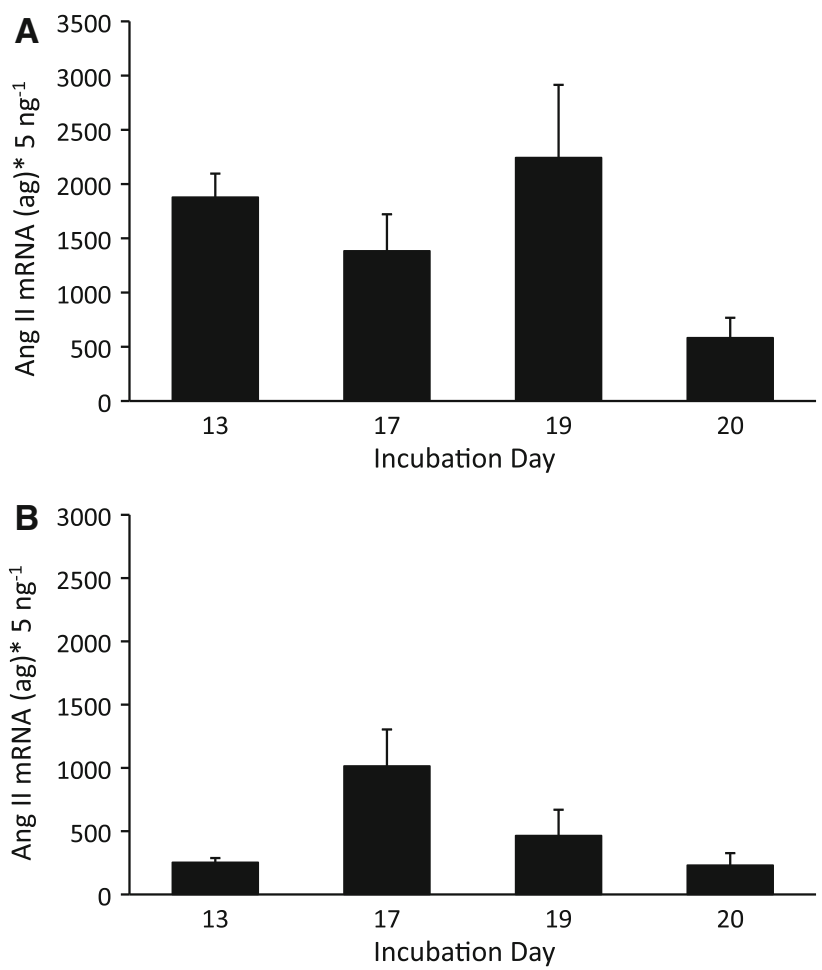

Fig. 5 The Ang II mRNA concentration per 5 ng of total RNA in a whole CAMs, and $\mathbf{b}$ hearts from embryonic chickens at 13, 17, 19, and 20 days of development. The data are presented as mean $\pm \mathrm{SE}$

\section{Discussion}

Ang II caused a dose-dependent hypertension increasing in intensity during the final days of embryonic maturation. 
Although the physiological response to Ang II increased with development, the mRNA levels for the Ang II receptor remained constant in embryonic hearts and CAMs. The pressure response to Ang II and the high level of endogenous peptide in the blood indicate that Ang II plays an important role in embryonic chicken cardiovascular development. However, the contribution of these elevated Ang II levels to maintaining basal cardiovascular function is unclear.

\section{Pharmacological response}

The $1,000 \mathrm{ng} / \mathrm{kg}$ dose of Ang II maximally increased $P_{\text {mean }}$ on all days studied, except day 13. At this dose, the intensity of the $P_{\text {mean }}$ change was dependent on embryonic age, with a distinct increase during the final days of incubation (Fig. 2a). The mechanisms underlying this increased Ang II response with age were not directly addressed in this study. Prior studies comparing early- and late-gestation fetal sheep demonstrated that kidney Ang II type-1 receptor mRNA expression and receptor density increase as a function of ontogeny (Robillard et al. 1995; Butkus et al. 1997). However, studies using cardiac tissue reported that Ang II type-1 receptor mRNA expression remained constant during the final trimester of sheep ontogeny or decreased from day 80 to the postnatal period (Margaret et al. 1998; Reini et al. 2009). Given that this issue is unresolved in fetal sheep and in our current findings, it would be difficult to ascribe the physiological pattern demonstrated here in embryonic chickens to a change in cardiovascular Ang II type-1 receptor gene expression. The increasing $P_{\text {mean }}$ response to Ang II could be attributed to a maturing adrenergic contribution in embryonic chickens. This suggestion is based on the previous finding that Ang II increases circulating catecholamine levels (both norepinephrine and epinephrine) in adult vertebrates (Carroll and Opdyke 1982). In addition, in adult chickens, Ang II results in an adrenergic-dependent vasoconstriction due to sympathetic nerve terminal release of catecholamines (Nishimura et al. 1981a, b; Nakamura et al. 1982; Nishimura et al. 2003). Embryonic chicken adrenal tissue also contains Ang II receptors, which could provide a mechanism for catecholamine release due to this peptide, similar to the mechanism seen in adult birds (Nishimura et al. 2003). Finally, the cardiovascular response to tyramine, a compound that causes catecholamine release from postganglionic neurons, increases in intensity as embryonic development progresses (Crossley 1999; Crossley et al. 2003b). If Ang II causes sympathetic nerve terminal release of catecholamines in the embryo, as in the adult, then this sympathetic maturation could explain the Ang II pressure pattern documented in our study. The increasing response to Ang II could be due to an increased capacity for this peptide to cause catechol- amine release from sympathetic terminals and/or adrenal tissue during chicken development.

Although embryonic chickens exhibited a clear hypertensive response to Ang II, the initial hypotension previously characterized in adult birds (Nakamura et al. 1982) was absent throughout development (Fig. 2a). This difference could be explained in part by the elevated levels of endogenous Ang II in the embryonic animal (Fig. 4). In adult chickens, the two-phase pressure response to Ang II requires two functioning systems: the nitric oxide pathway and functional sympathetic nerve terminals (where Ang II binds, causing a release of catecholamines) (Nishimura et al. 1981a, b; Nakamura et al. 1982; Hasegawa et al. 1993; Nishimura et al. 1994). The endothelial-dependent nitric oxide pathway is functional in isolated aortic rings taken from 19-day-old chicken embryos (Nishimura et al. 2003). Embryonic chickens, like fetal mammals, exhibited plasma levels of Ang II (Fig. 4) three to four times higher than those found in adult birds under normal hydrated states (Gray and Simon 1985; Kobayashi and Takei 1982). These elevated levels could saturate the Ang II-induced release of nitric oxide in embryonic chickens, as previously suggested by Nishimura et al. (2003), preventing the additional Ang II injected during this study from producing a drop in pressure. Regardless of the difference in adult and embryonic hypotensive response, the increasing hypertensive response to the hormone with age, combined with the elevated levels of the peptide in the blood, suggest that Ang II plays a role in maintaining cardiovascular function in embryonic chickens.

\section{Blockade of the Ang II receptor}

As noted, embryonic White Leghorn chickens lack neuralmediated regulation of cardiovascular function throughout the majority of development (Tazawa et al. 1992; Altimiras and Crossley 2000; Crossley and Altimiras 2000; Crossley et al. 2003b). Basal cardiovascular function may instead be maintained by systemically released hormones such as Ang II during chicken ontogeny. To verify this, we used the Ang II receptor-blocking agent $\left[\mathrm{Sar}^{1}\right.$ ile $\left.^{8}\right]$ Ang II, an effective nonspecific competitive peptide antagonist in adult chickens and isolated embryonic vessels (Nakamura et al. 1982; Kempf and Corvol 2001; Nishimura et al. 2003). However, the blocking agent had no impact on the embryonic hypertensive response to the peptide until day 21 of development (Fig. 3). Although the blocking agent was developed for use in mammalian studies, it is also effective in adult chickens, despite the $25 \%$ amino acid difference between the mammalian and chicken Ang II type-1 receptor (Nishimura 2001).

We can only speculate about the basis for the differing blockade capacity in adult versus embryonic chickens. 
Differences in the Ang II type-1 receptor are unlikely to be the cause; we cloned and sequenced the embryonic Ang II receptor cDNA, which was $99.0 \%$ homologous to the adult sequence (Kempf et al. 1996; Crossley et al., unpublished data). Although not directly studied in the current work, multiple Ang II receptor subtypes with differing functions have been identified in mammals (Chiu et al. 1989), and it is conceivable that a second Ang II receptor subtype may account for the persistent Ang II actions following treatment with $\left[\mathrm{Sar}^{1}{ }^{1} \mathrm{ile}^{8}\right]$ Ang II. Two Ang II receptors, types 1 and 2, have been suggested based on blockade studies conducted using isolated embryonic chicken cardiomyocytes (Bkaily et al. 2005). Further, a predicted Ang II type-2 receptor sequence has been indentified in the chicken genome (Accession \#XM 426266). These data, coupled with our findings, indicate that a second receptor subtype is present in embryonic chickens, which could account for the persistent Ang II response following treatment with the blocking agent. Although this argument is plausible, the contribution of Ang II to resting cardiovascular function in embryonic chickens remains unclear, due to the limited blocking capacity of $\left[\mathrm{Sar}^{1}\right.$ ile $\left.^{8}\right]$ Ang II in this study.

\section{Ang II mRNA expression patterns}

Ang II type-1 receptor mRNA in embryonic hearts and CAMs remained constant during the period of development studied, while the physiological response to the peptide increased (Fig. 5a, b). Protein quantification was not conducted in the current study, but protein concentration may increase even if mRNA for the receptor is constant. This could account for the increasing physiological response to the peptide. If gene expression levels are indicative of the number of Ang II receptors present in the tissue, then the maturation of an intracellular signaling mechanism could account for our findings. In addition, the increased pressure response intensity could be attributed to the development of the vascular smooth muscle contractile apparatus, as previously suggested (Le Noble et al. 2000). Both scenarios would account for the mismatch between the gene expression for the receptor and the development of the physiological response to Ang II in embryonic chickens.

In conclusion, using an integrative approach to investigate the feasibility of Ang II as a cardio-regulatory mechanism, we found evidence that it plays an important role in cardiovascular development in chickens. We determined that there is an increasing pressure response to the peptide with embryonic development. Nevertheless, the contribution of Ang II in maintaining basal $P_{\mathrm{A}}$ and $f_{\mathrm{H}}$ in embryonic chickens remains unclear, due to the limited receptorblocking capacity of $\left[\mathrm{Sar}^{1} \mathrm{ile}^{8}\right]$ Ang II. Our hypothesis that the $P_{\mathrm{A}}$ response to Ang II would increase with development was confirmed. However, this increase could not be attributed to any change in Ang II type-1 receptor gene expression or to a change in circulating levels of the peptide. The data also suggest that the cardiovascular response to Ang II must undergo changes during the embryonic period to resemble changes previously characterized in adult chickens. We have presented several theories that would account for these differences. Further study is needed to clarify how the regulatory function of Ang II matures, and ultimately, to establish its role in maintaining basal cardiovascular function during development in chickens.

Acknowledgments We are greatly indebted to Robert Webber, Krista Wherly, Samantha Louey, and George Giraud for their assistance in completing this project. We would also like to acknowledge Janna Mabey, Renee Mabey, Kevin Tate, Justin Swart, and Diane Darland for their editing suggestions on the manuscript. This research was supported by American Heart Association Postdoctoral fellowship \#0120044Y, National Science Foundation Career Award IBNIOS0845741 to D.A.C. II, funding from NSF grant IBN-IOB04445680 to J.W.H., and NIH grant IBN-2PO1HD34430 to K.T.

Open Access This article is distributed under the terms of the Creative Commons Attribution Noncommercial License which permits any noncommercial use, distribution, and reproduction in any medium, provided the original author(s) and source are credited.

\section{References}

Aceto JF, Baker KM (1990) [Sar] angiotensin II receptor-mediated stimulation of protein synthesis in chick heart cells. Am J Physiol Heart Circ 258:H806-H813

Altimiras J, Crossley DA II (2000) Control of blood pressure mediated by baroreflex changes of heart rate in the chicken embryo (Gallus gallus). Am J Physiol Regul 278:R980-R986

Assali NS, Brinkman CR, Woods R, Dandavino A, Nuwayhid B (1978) Ontogenesis of the autonomic control of cardiovascular functions in the sheep. In: Longo LD, Reneau DD (eds) Fetal and newborn cardiovascular physiology. Garland STPM Press, New York, pp 47-92

Baker KM, Aceto JF (1990) Angiotensin II stimulation of protein synthesis and cell growth in chick heart cells. Am J Physiol Heart Circ 259:H610-H618

Bkaily G, El-Bizri N, Nader M, Hazzouri KM, Riopel J, Jacques D, Regoli D, D'Orleans-Juste P, Gobeil JF, Avedanian L (2005) Angiotensin II induced increase in frequency of cytosolic and nuclear calcium waves of heart cells via activation of AT1 and AT2 receptors. Peptides 26(8):1418-1426

Butkus A, Albiston A, Alcorn D, Giles M, McCausland J, Moritz K, Zhou J, Wintour EM (1997) Ontogeny of angiotensin II receptors, type 1 and 2 in ovine mesonephros and metanephros. Kidney Int 51:628-636

Carroll RG, Opdyke DF (1982) Evolution of angiotensin II-induced catecholamine release. Am J Physiol Regul 243:R65-R69

Chiu AT, Herblin WF, McCall DE, Ardecky RJ, Carini DJ, Duncia JV, Pease LJ, Wong PC, Wexler RR, Johnson AL, Timmermans PBMWM (1989) Identification of angiotensin II receptor subtypes. Biochem Biophys Res Commun 165(1):196-203

Cowley AWJ, Miller JP, Guyton AC (1978) Open-loop analysis of the renin angiotensin system in the dog. Circ Res 28:568-581

Crossley II DA (1999) Development of cardiovascular regulation in embryos of the domesitic fowl (Gallus gallus), with partial 
comparison to embryos of the desert tortoise (Gopherus agassizii). Dissertation, University of North Texas

Crossley DA II, Altimiras J (2000) Ontogeny of cholinergic and adrenergic cardiovascular regulation in the domestic chicken (Gallus gallus). Am J Physiol Regul 279:R1091-R1098

Crossley DA II, Bagatto BP, Dzialowski EM, Burggren WW (2003a) Maturation of cardiovascular control mechanisms in the embryonic emu (Dromiceius novaehollandiae). J Exp Biol 206:27032710

Crossley DA II, Burggren WW, Altimiras J (2003b) Cardiovascular regulation during hypoxia in embryos of the domestic chicken Gallus gallus. Am J Physiol Regul 284:R219-R226

Faber JJ, Green TJ, Thornburg KL (1974) Arterial blood pressure in the unanesthetized fetal lamb after changes in fetal blood volume and haematocrit. Q J Exp Physiol 59:241-255

Fluharty SJ, Reagan LP (1989) Characterization of binding sites for the angiotensin II antagonist 125I-[Sarc1, Ile8]- angiotensin II on murine neuroblastoma N1E-115 cells. J Neurochem 52:13931400

Giraud GD, Faber JJ, Jonker S, Davis L, Anderson DF (2005) Intravascular infusions of plasma into fetal sheep cause arterial and venous hypertension. J Appl Physiol 99:884-889

Goutsouliak V, Rabkin SW (1998) Comparison of angiotensin II type1 and type- 2 receptor antagonists on angiotensin II induced Ip3 generation in cardiomyocytes. Gen Pharmacol 30(3):367-372

Gray DA, Simon E (1985) Control of plasma angiotensin II in a bird with salt glands (Anas platyrhynchos). Gen Comp Endocrinol 60:1-13

Hasegawa K, Nishimura H, Khosla M (1993) Angiotensin II-induced endothelium-dependent relaxation of fowl aorta. Am J Physiol Regul 264:R903-R911

Iwamoto HS, Rudolph AM (1981a) Effects of angiotensin II on the blood flow and its distribution in fetal lambs. Circ Res 48:183188

Iwamoto HS, Rudolph AM (1981b) Role of renin-angiotensin system in response to hemorrhage in fetal sheep. Am J Physiol Heart Circ 240:H636-H854

Kempf H, Corvol P (2001) Angiotensin receptor(s) in fowl. Comp Biochem Physiol 128:77-78

Kempf H, Le Moullec J-M, Corvol P, Gasc J-M (1996) Molecular cloning, expression and tissue distribution of a chicken angiotensin II receptor. FEBS Lett 399:198-202

Kempf H, Corvol P, Gasc J-M (1999) Expression of the chicken angiotensin II receptor: atypical pattern compared to its mammalian homologues. Mech Dev 84:177-180

Kobayashi H, Takei Y (1982) Mechanisms for induction of drinkiing with special reference to angiotensin II. Comp Biochem Physiol 71A:485-494

Le Noble FAC, Hekking JWM, Van Straaten HWM, Slaaf DW, Boudier HAJS (1991) Angiotensin II stimulates angiogenesis in the chorio-allantoic membrane of the chick embryo. Eur J Pharmacol 195:305-306

Le Noble FAC, Ruijtenbeek K, Gommers S, De Mey JGR, Blanco CE (2000) Contractile and relaxing reactivity in carotid and femoral arteries of chicken embryos. Am J Physiol Heart Circ 278:H1261-H1268

Liu HK, Guild SJ, Ringwood JV, Barrett CJ, Leonard BL, Nguang SK, Navakatikyan MA, Malpas SC (2002) Dynamic baroreflex control of blood pressure: influence of the heart vs. peripheral resistance. Am J Physiol Regul 283:R533-R542

Lumbers ER, Gunn AJ, Zhang DY, Wu JJ, Maxwell L, Bennet L (2001) Nonimmune hydrops fetalis and activation of the reninangiotensin system after asphyxia in preterm fetal sheep. Am J Physiol Regul 280:R1045-R1051

Malpas SC (2002) Neural influences on cardiovascular variability: possibilities and pitfalls. Am J Physiol Heart Circ 282:H6-H20
Margaret SE, Petershack JA, Mathews KA, Segar JL (1998) Ontogeny and regulation of cardiac angiotensin type 1 and 2 receptors during fetal life in sheep. Pediatr Res 44(3):323-329

Mulder ALM, Van Golde JMCG, Van Goor AAC, Giussani DA, Blanco CE (2000) Developmental changes in plasma catecholamine concentrations during normoxia and acute hypoxia in the chick embryo. J Physiol (Lond) 527(3):593-599

Nakamura Y, Nishimura H, Khosla MC (1982) Vasodepressor action of angiotensin in conscious chickens. Am J Physiol Heart Circ 243:H456-H462

Nishimura H (2001) Angiotensin receptors-evolutionary overview and perspectives. Comp Biochem Physiol 128A:11-30

Nishimura H, Nakamura Y, Taylor AA, Madey MA (1981a) Reninangiotensin and adrenergic mechanisms in control of blood pressure in fowl. Hypertension 3(Suppl I):I41-I49

Nishimura H, Madey MA, Mugaas JN, Knosla MC, Crofton JT (1981b) Radioimmunoassay of fowl angiotensin I. Gen Comp Endocrinol 45:262-272

Nishimura H, Nakamura Y, Sumner RP, Khosla MC (1982) Vasopressor and depressor actions of angiotensin in the anesthetized fowl. Am J Physiol Heart Circ 242:H314-H324

Nishimura H, Walker OP, Patton CM, Madison AB, Chiu AT, Keiser J (1994) Novel vascular angiotensin receptor subtypes and signal pathway in fowl. Am J Physiol Regul 267:R1174-R1181

Nishimura H, Yang Y, Hebert C, Gase J-M, Ruijtenbeek K, De Mey J, Struijker Boudier HAJ, Corvol P (2003) Maturation-dependent changes of angiotensin receptor expression in fowl. Am J Physiol Regul 285:R231-R242

Persson PB (1996) Modulation of cardiovascular control mechanisms and their interaction. Physiol Rev 76(1):193-224

Persson PB, Stauss H, Chung O, Wittmann U, Unger T (1992) Spectrum analysis of sympathetic nerve activity and blood pressure in conscious rats. Am J Physiol Heart Circ 263:H1348-H1355

Ploucha JM, Fink GD (1986) Hemodynamics of hemorrhage in the conscious rat and chicken. Am J Physiol Regul 251:R846-R850

Regoli D, Park WK, Rioux F (1974) Pharmacology of angiotensin. Pharm Rev 26(2):69-123

Reini AS, Wood CE, Keller-Wood M (2009) The ontogeny of genes related to ovine fetal cardiac growth. Gene Expr Patterns 9:122-128

Rhen T, Metzger K, Schroeder A, Woodward R (2007) Expression of putative sex-determining genes during the thermosensitive period of gonad development in the snapping turtle, Chelydra serpentina. Sex Dev 1(4):255-270

Robillard JE, Page WV, Mathews MS, Schutte BC, Nuyt M, Segar JL (1995) Differential gene expression and regulation of renal angiotensin II receptors (AT1 and AT2) during fetal life in sheep. Pediatr Res 38(6):896-904

Romanoff AL (1960) The avian embryo. Structural and functional development. MacMillan Company, New York

Romanoff AL (1967) Biochemistry of the avian embryo. A quantitative analysis of prenatal development. Interscience, New York

Tazawa H, Hashimoto Y, Doi K (1992) Blood pressure and heart rate of the chick embryo (Gallus domesticus) within the egg: responses to autonomic drugs. In: Hill RB, Kuwasawa K, McMahon BR, Kuramoto T (eds) Phylogenetic models in functional coupling of the CNS and the cardiovascular system. Karger, Basel, pp 86-96

Thornburg KL, Morton MJ (1986) Filling and arterial pressures as determinants of left ventricular stroke volume in fetal lambs. Am J Physiol Heart Circ 251:H961-H968

Topouzis S, Catravas J, Ryan J, Rosenquist T (1992) Influence of vascular smooth muscle heterogeneity on angiotensin converting enzyme activity in chicken embryonic aorta and in endothelial cells in culture. Circ Res 71:923-931

van Tuinen M, Sibley CG, Hedges SB (2000) The early history of modern birds inferred from DNA sequences of nuclear and mitochondrial ribosomal genes. Mol Biol Evol 17(3):451-457 